
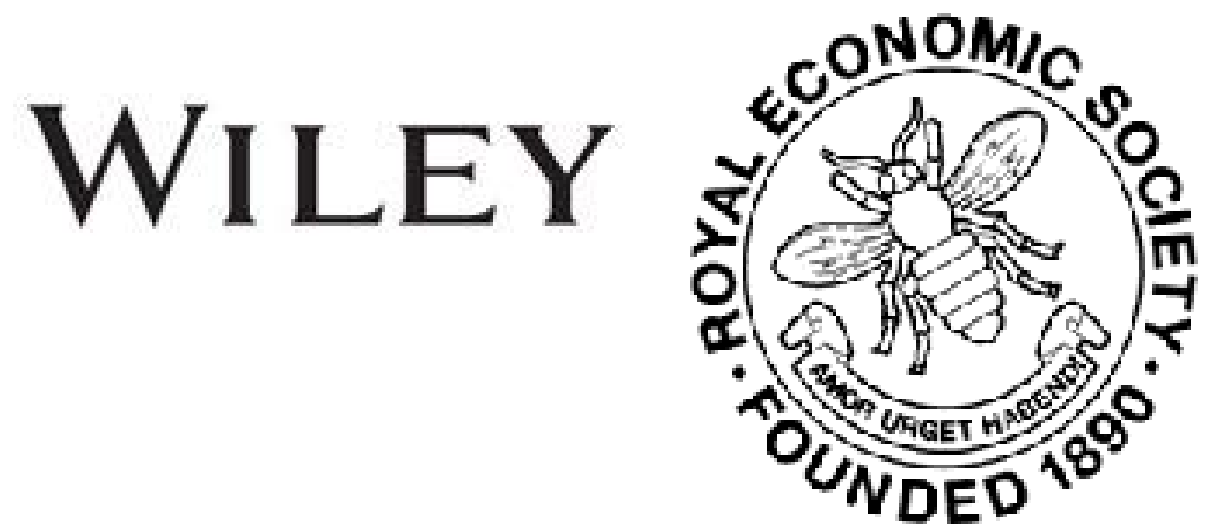

Ireland's Place in the Financial System of the United Kingdom Author(s): C. F. Bastable

Source: The Economic Journal, Vol. 6, No. 22 (Jun., 1896), pp. 185-203

Published by: Wiley on behalf of the Royal Economic Society

Stable URL: http://www.jstor.org/stable/2956497

Accessed: 27-06-2016 04:29 UTC

Your use of the JSTOR archive indicates your acceptance of the Terms \& Conditions of Use, available at

http://about.jstor.org/terms

JSTOR is a not-for-profit service that helps scholars, researchers, and students discover, use, and build upon a wide range of content in a trusted digital archive. We use information technology and tools to increase productivity and facilitate new forms of scholarship. For more information about JSTOR, please contact support@jstor.org.

Wiley, Royal Economic Society are collaborating with JSTOR to digitize, preserve and extend access to The Economic Journal 


\section{IRELAND'S PLACE IN THE FINANCIAL SYSTEM OF THE UNITED KINGDOM.}

THERE are many evidences of the revival of interest in financial questions. The rapid increase in expenditure and the long-continued agricultural depression have led to a more careful examination of the distribution of both imperial and local taxation. One important division of direct taxation-the death duties-has been radically altered, and an attempt is even now being made to reduce the pressure of rates on the holders of land. In the same way some old financial controversies have been reopened, and in particular the alleged over-taxation of Ireland has been forced into a position of some prominence. An unfortunate fatality has delayed the appearance of a Report from the Commission appointed to investigate this matter, but in some quarters, and especially in Ireland, it has been assumed that the issue is already decided. As most of the material facts and some of the chief arguments have been put before the public, it seems not unfitting to consider the case as an instructive example of a class of problems hitherto insufficiently treated by writers on finance.

For this purpose three lines of inquiry are naturally suggested, viz.: (1) the historical, (2) the statistical, and (3) the economic. All three come within the domain of public finance in the wider sense; but the last is more peculiarly a financial question and might even be exclusively described by that term, history and statistics being rather employed as auxiliaries, indispensable ones indeed, but still preliminary and subordinate.

\section{I.}

Though a great deal of matter has been collected respecting the financial position of Great Britain and Ireland at the time immediately preceding the Union, and the mode and conditions under which the two Exchequers were amalgamated have been 
discussed ad nauseam, ${ }^{1}$ little or no notice has been taken of the earlier relations. It is essential to bear in mind that up to 1782 Ireland was a dependency of Great Britain, having institutions formed on the English model. Its revenue system, though in general outline similar to that of England, was more archaic ; ${ }^{2}$ the hereditary revenues in Ireland remained at the disposal of the Crown, and the later developments of British taxation were not applied. Thus the land tax, originally imposed on property in general, never existed in Ireland; the excise and customs duties, moreover, were insufficiently developed. The broad result was that Irish taxation was much lighter than that imposed in Great Britain. ${ }^{3}$ In fact, it may be said that the cost of supporting the expanding British Empire fell altogether on England and, with some modifications, Scotland. Most of the difficulties that arose were the result of this peculiar condition. Adam Smith's approval of a federation of the Empire was based on the desirability of securing adequate contributions from Ireland and the American Colonies towards the cost of defence in which they were vitally interested. He does not hesitate to propose the extension of the British system of taxation to Ireland and the Colonies, with the condition that representation was to be proportioned to the produce of taxation. ${ }^{4}$ It is hardly open to question that Ireland was free from the heavy taxation levied in Great Britain in the second half of the eighteenth century. The cheapness of intoxicating drinks was particularly noticeable. Arthur Young's judgment on this point is worth quoting:-

' The cheapness of whisky with which a man may get dead drunk for twopence is an enormity too great to be borne. The morals, health, peace, industry, agriculture, manufactures, commerce, and wealth of the Kingdom, are all materially injured by the cheapness of this vile beverage : there is not an object in Ireland which would yield a more productive revenue; at the same time that every shilling Government got would be half-a-crown benefit to the public: a judicious and well-collected excise on this liquor would raise an immense revenue. All other spirits, wines and tobacco are also very well able to bear much heavier taxes than they labour under at present.' 5

1 See the 'Memorandum' prepared for the use of the Financial Relations Commission, by Sir E. W. Hamilton, and printed as Appendix I. to the Minutes of Evidence.

2 The history of the Irish revenues is given by Sinclair, History of the Public Revenue of the British Empire, 3rd ed., 1804, vol. iii., p. $151 \mathrm{sq}$.

3 Arthur Young shows this clearly by a comparison of the two countries, though his tests are quite unscientific. Tour in Ireland (Bohn's edition), vol. ii., p. 226.

4 Wealth of Nations, book v. ch. iii. (Nicholson's edition) p. 397. Adam Smith further maintained that it was ' not contrary to justice that both Ireland and America. should contribute towards the discharge of the public debt of Great Britain.' Ib. p. 402 .

5 Tour in Ireland, vol. ii., pp. 230, 231. 
A careful native observer took the same view. Dr. Crumpe, in his valuable Essay, dwells forcibly on the prevalence of drunkenness in Ireland, and advises the imposition of heavy taxation on the stronger drinks, with lower rates or complete exemption for the lighter kinds; in fact, the policy at present adopted in the United Kingdom. ${ }^{1}$

The Irish revenue, accordingly, had not risen in the same ratio as the British one. In 1701 the English revenue was $£ 3,895,000$, in 1759 the revenue of Great Britain was $£ 5,691,000$, in 1792-93 it had reached $£ 17,300,000$. The Irish revenue for 1701 was $£ 627,000$, in the first two years of George III.'s reign, $1760-61$, it came to $£ 1,463,000$ or $£ 731,500$ per annum, for the year ending March 25th, 1793, it was $£ 1,363,000 .{ }^{2}$ Thus, the increase of British revenue between 1701 and 1759 was about 40 per cent.; the Irish increase for, approximately, the same period was under 5 per cent. From the accession of George III. to the opening of the Revolutionary War the British revenue had increased threefold, while the Irish one had hardly doubled. Making every allowance for the more rapid industrial development of northern England, and the south of Scotland, and the oppressive restrictions on the Irish trade, it is nevertheless clear that Irish taxation had not grown with that of the larger island.

The crisis of the Revolutionary War brought the difficulties of the situation more prominently into notice. Irish taxation had to be increased, ${ }^{3}$ but the immense loans contracted by the British Government made an attempt at combination of the fiscal systems of the two countries even harder than before, but the political obstacles were overcome and the Union was finally arranged on the basis that each country was to be responsible for its own debt, and that Ireland was henceforth to contribute two-seventeenths of the total joint expenditure of the United Kingdom. ${ }^{4}$ This proportion, probably calculated on very imperfect.

${ }^{1}$ See his Essay on the best Means of providing Employment for the People (1793), pp. 52, 53, and 185, 186.

2 See Sinclair, op. cit. vol. ii., pp. 13-22, vol. iii., p. 182 ; Dowell, History of Taxation, vol. ii., p. 206; Hamilton, Memorandum, p. 4.

3 In 1799, 1800 the Irish revenue was $£ 3,017,000$.

${ }^{4}$ As there was no income-tax in Ireland, Lord Castlereagh considered 'that the criterion next in order is the joint result of commerce and consumption, and that. this may be satisfactorily ascertained by a review of their exports and imports together with the quantities and value of the chief articles of their consumption.' It seems highly probable that the representation given to Ireland, 2 out of 13 , was calculated with regard to the estimated population, 2 out of 6 or 7 , and the tax contribution, 2 out of 17 . 
data, was to continue until the debt charges were brought into the same ratio, when the complete fiscal union proposed by Adam Smith might be carried out.

The period 1801-16 shows the Irish revenue constantly falling short of the assigned proportion, and the balance being debited to her account, until her debt came into, or rather above, the ratio of contribution just stated. Such is the apparently simple result of the mass of figures and controversy that has been piled up. The matter may be put in one of two ways. We may say that Ireland paid at the rate of two-seventeenths for the period 1801-16 and then came under the system of common taxation; or, if we desire to keep to facts, we can say that Ireland contributed about one-thirteenth of the total revenue collected ${ }^{1}$ during this transitional period, and that at its close she came into the general British revenue system with its heavy burden of debt.

The further history is one of gradual assimilation. By degrees the spirit and tobacco duties were worked up to a common level. Eleven years after its re-establishment in Great Britain the income-tax was applied to Ireland, and the general revenue system was made as uniform as seemed advisable. It is noticeable, however, that several old direct taxes were not applied to Ireland. Thus the land tax, which had practically become a rent charge, remained peculiar to Great Britain; so did the inhabited house duty and also certain direct consumption taxes, described as establishment licenses. ${ }^{2}$

Coincidently with this fiscal development a series of remarkable economic changes have been in progress. The wealth and population of Great Britain have continuously increased, ${ }^{3}$ and the position of all classes of society has been improved. In Ireland, on the other hand, the population which increased rapidly in the period $1800-45$, has decreased with equal speed in the period 1846-90, and the accumulation of wealth has not been very striking or remarkable. The whole weight of evidence goes to establish an extreme amount of misery amongst the mass of the Irish population in the quarter of a century immediately preceding the famine of $1846,{ }^{4}$ and the improve-

$1 £ 77,844,000$ against $£ 927,659,000$ collected in Great Britain, or very nearly 7.75 per cent. Hamilton, Memorandum, pp. 25-6.

2 It may be added that all these taxes are suited for local rather than imperial revenue, and might be surrendered to the local authorities with advantage.

3 Perhaps an exception ought to be made as to increase of wealth for the period 1837-45, one of special stress and hardship for Great Britain.

4 The evidence on this point is absolutely overwhelming. See particularly the 
ment from that lowest level, though decided and well-established, has not been so speedy as might have been hoped. Under such circumstances the application of new taxes naturally appeared harsh and unjust. Though very little tobacco was grown in Ireland, the prohibition of its cultivation in 1832. seemed an interference with industry. The increases of the spirit duties pressed at once on a favourite article of consumption by the people, and checked the operations of an important. industry which afforded a market for agricultural produce. Even the extension of the income-tax, though it only touched a small section of the people, and one quite able to bear it, afforded ar ground of complaint. Irish taxation per head of population rose rapidly, while that of Great Britain showed no such decided movement. Moreover, the course of English financial policy had brought about a complete emancipation of industry, and conferred great benefits on the artisan class in particular. This class, however, formed but a small part of the Irish population; the main interests of the country were agricultural, and one prominent part of the free trade policy-the Repeal of the Corn Laws-seemed to deprive Irish agriculturists of an advantage that they had previously enjoyed. ${ }^{2}$ Such considerations help to explain the dissatisfaction felt by most Irishmen with regard to the financial treatment of their country. Political conditions have made this sentiment a practical force, and it is therefore necessary to test the statistical bases on which the quẹstion has to be discussed.

\section{II.}

The difficulties and pitfalls of statistical inquiry have become proverbial, and the economic student, compelled to deal with such investigations is inclined, to repeat the emphatic dictum of reports of the Devon Commission and the less known Commission on the Poor Law. Carleton's novels give a very graphic picture of the real life of the peasantry about this time.

1 The improvement in house accommodation and the higher wages of labour are the most significant marks of advance.

2 The Irish landlords as a class have been strongly protectionist, but it is doubtful whether the Repeal of the Corn Laws injured them as much as is alleged. The export trade in wheat was notoriously fluctuating (see the notice on this point in Tooke's History of Prices, vol. iv., pp. 33-5), varying from under 175,000 quarters in 1839-40 to over 700,000 quarters in 1844-5, or a difference of 300 per cent., and its highest. amount was not very large. The rapid development of the industrial districts of Great Britain supplied an expanding market for Irish produce that compensated the reduced demand for wheat. The real evil was the suddenness of the change in the agricultural system, which however was necessitated by the circumstances of the time. See Cairnes' Political Essays, pp. 136-141. 
Adam Smith, 'I have no great faith in political arithmetic.' But even more valuable than this lesson of scepticism is the further one of discrimination. From 'figures' that are 'facts' to those that are 'absolute fictions' there is a gradual transition through many intermediate classes. To say exactly how much weight should be given to each class; how far it is possible to generalise or to compare ; and whether the available material is good enough for drawing a practical conclusion-these are the real problems,

Some of the data for a comparison between Ireland and Great Britain are as perfect as can reasonably be expected. Thus, the population returns and the statements as to amounts of revenue oollected can be accepted without question. But unfortunately these are by themselves of little use. To employ population returns some assumption or proved fact as to relative income must be added; while collected revenue in two countries with common taxation, and complete freedom of trade, is not conclusive as to even the immediate incidence of taxation on commodities, since goods paying duty in one country may be consumed in the other. Thus a process of adjustment is needed, but this at once weakens the statistical basis on which we have to work. A similar hindrance arises in respect to the treatment of other taxes. Great Britain and Ireland are not two totally distinct economic regions. 'The people constituting the United Kingdom are closely intermixed in their business relations. Property in one part of the kingdom is held by persons resident in another part; there are not a few whose domicile is by no means certain. . . . There is, moreover, a considerable amount of foreign property belonging to people in all parts of the United Kingdom, but assessed exclusively in the metropolis.' ' Consequently the real is not the same as the apparent distribution of taxation. Allowances involving an element of conjecture have to be made in order to obtain the supposed 'true' figures. To show the difference thus arising we may take the amounts of 'collected' and 'true' revenue for the year 1892-93 in Great Britain and Ireland respectively. ${ }^{2}$ (See Table on p. 191.)

Imperial revenue does not, however, exhaust the list of charges. Local taxation has a prima facie claim to be taken into account; in addition' to 'taxes' it would seem that we should

1 Giffen, Growth of Capital, pp. 63-4.

2 See Hamilton, Memorandum, pp. 55 and 61 . It should be added that these figures have undergone further adjustment in connexion with the estimated transfers of spirits and tobacco. They, further, omit the Irish incomes received in London and paying duty there. Some revenue regarded as Imperial is excluded from the total 'true' revenue. 
compare the amount of 'rates' in the two great divisions of the United Kingdom. Exact returns under this head are harder to obtain; the accounts are more complicated and not easily put on a precisely similar footing. One attempt at comparison gives the local taxation of Ireland for 1891-92 as $£ 2,810,000$, while that for Great Britain is put approximately at $£ 39,054,000 .{ }^{1}$ But quite apart from such minor details there is the broad objection to using the various items of revenue to form a total amount. Some imperial revenue is not tax revenue; but the greater part of the income of local bodies is either (1) non-tax, or (2) for reproductive purposes. The result obtained by summing up the imperial and local revenues is a mere arithmetical expression of no value until analysed.

\begin{tabular}{|c|c|c|c|c|}
\hline- & \multicolumn{2}{|c|}{ Collected Revenne. } & \multicolumn{2}{|c|}{ 'True' Revenue. } \\
\hline $\begin{array}{l}\text { Great Britain . } \\
\text { Ireland } . . . . . .\end{array}$ & $\begin{array}{c}\text { 000's omitted. } \\
£ 87,927 \\
£ 9,349\end{array}$ & $\begin{array}{c}\text { Per cent. } \\
90 \cdot 39 \\
9 \cdot 61\end{array}$ & $\begin{array}{c}000 \text { 's omitted. } \\
£ 88,455 \\
£ 7,644\end{array}$ & $\begin{array}{c}\text { Per cent. } \\
92.05 \\
7.95\end{array}$ \\
\hline Total ..... & $£ 97,276$ & $100 \cdot 0$ & $£ 96,099$ & $100 \cdot 0$ \\
\hline
\end{tabular}

Like difficulties surround the amounts of expenditure. Should any distinction be drawn between imperial and local outlay? If so, on what principles should the boundary line be fixed? Granting the principle of division to be determined, how are the available facts to be handled in order to extract the truth? These are the questions that at once suggest themselves, and require for their solution a reference to the general doctrine of scientific finance. The examination of the returns of expenditure may therefore be conveniently postponed.

The statistics as to revenue and expenditure need careful consideration and adjustment; they, however, supply at least a groundwork of definite facts. The next set of statistics though of the utmost importance is less satisfactory in this respect. No judgment as to the financial resources of a country or the burden imposed on it by a given system of taxation, can be pronounced without reference to the income that its inhabitants enjoy. Statistics of property or trade may furnish additional light, but 'the necessaries and conveniences of life which it annually consumes' 2 are the primary measure of its resources. Neverthe-

1 Hamilton, p. 62. The Scotch return is two years older than the English one; therefore the total for Great Britain is inexact.

2 Wealth of Nations, opening paragraph : 'together with its fresh savings' ought in consistency to be added. 
less, there are few questions to which it is harder to give a precise answer. All the efforts of skilled statisticians only result in approximations of more or less value. A good starting point for investigation is supplied by the income-tax assessmentswhich in their special form are peculiar to the United Kingdom --though it must be remembered that they are only a starting point. Like all returns for taxation purposes they are affected by evasion, an influence which varies from schedule to schedule, from class to class within each schedule, and from person to person in each class. How much taxable income thus escapes cannot be accurately determined. A second difficulty is found in the composite nature of the income-tax. ${ }^{1}$ The methods of imposition vary so much that there is in strictness no accurate basis of comparison. Official salaries and the profits of great public companies exposed to complete supervision are not to be compared with the assessed gains of private traders. The most glaring instance is, however, the treatment of farmers' profits. As regards assessment schedule $B$ is practically schedule $A$ repeated; while the payment under this head is described by the highest official authority as ' a complete farce, a complete and absolute farce.' ${ }^{2}$ Thirdly, working class income is altogether exempt, and this, it is probable, carries with it a good deal of small dealers' profits. An attempt to compare British and Irish income is considerably hindered by the existence of such difficulties. The whole mass of farming income practically disappears from view, the labourer's income never comes into sight; so that rents, salaries, investments, and some classes of profits are the constituents of the income that the income-tax schedules disclose, in some instances imperfectly. A much more thorough inquiry based on careful examination of the economic conditions of life and the actual course of business is needed before drawing any conclusion from the existing income-tax returns.

Under such circumstances the most natural course is to seek an independent estimate of income by taking the masses of commodities and services that come into use during the yearin the technical language of German economists to employ the 'real,' as distinct from the 'personal' method. ${ }^{3}$ Very ingenious

1 'We are too much in the habit of speaking of this impost as merely a simple tax ; it is rather a code or system of taxation.' Gladstone, Financial Statements, p. 20 .

2 Sir A. Milner before the Royal Commission on Agricultural Depression. Answer to Question 64,033.

3 Cf. Roscher, Grundlagen, § 146; Wagner, Grundlegung der Politischen Ökonomie, 1er Theil, pp. $415 s q$. 
calculations have been made on this method for Irish income by Dr. Grimshaw and Sir R. Giffen, ${ }^{1}$ but they contain too many conjectural elements to admit of their acceptance without more elaborate efforts at verification. Average estimates of produce made from returns gathered by a large number of comparatively untrained officials can only be accepted within wide limits. ${ }^{2}$ The necessity of using prices as supplying a common measure introduces a further element of error. ${ }^{3}$ Broad averages have to be taken, but they are in most cases misleading. The quantities sold at each price and also the amount of surplus and bye-produce should be taken into account.

For these reasons it seems clear that the existing estimates. as to Irish income based on the 'real' method, though highly interesting and suggestive, are not in any way conclusive. We may justly apply to them the weighty judgment of Sir R. Giffen in another and somewhat similar case, and say that they 'are not good enough for projects of changes in taxation where anything like precision is required. The calculations may be, and no doubt are, useful for other purposes, but they are not good enough for this.' 4

Another objection should be added. For a just comparison it is necessary to have a corresponding estimate of British income framed on the 'real' method, and to place it beside the parallel figures for Ireland. This is an evident logical requirement; but unfortunately no such attempt has been made. ${ }^{5}$ The labour involved would, no doubt, be immense, and the results in a

1 See the evidence of Dr. Grimshaw to the Financial Relations Commission, vol. i., pp. 108-128, 144 sq., and the Memorandum drawn up by Sir R. Giffen, vol. ii., pp. 162-6, 176-7.

2 As to the defects of the agricultural statistics in Ireland, see the evidence of $\mathrm{Mr}$. Murrough O'Brien, Financial Relations Commission, Questions 6,870 sq. He characterises them as 'perfectly abs̀urd.'

3 The principal difficulties are (1) the intermixture of capital and income, e.g. in the case of cattle, some are sold, some are held on ; 2 the proper allowance for home consumption-if a small farmer maintains his family, though he makes no. money profit, he yet has an income; (3) the determination of the true prices of produce. Thus if Sir R. Giffen had substituted $7 d$. for $5 d$. as the price per gallon for milk it would have raised his figure for dairy produce by $£ 4,400,000$. The contract prices of milk for eleven Irish union workhouses are given in vol. iv. of the Reports of the Labour Commission on 'The Agricultural Labourer.' They range from $5 d$. to $11 \frac{1}{2} d$., and average at $7 d$. The date in each case is 1892 or 1893 . Mr. Turnbull's estimate for the United Kingdom is almost precisely $7 d$. per gallon. Royal Com. mission on Agricultural Depression, Question 59,337. Mr. Bear puts the cost of production of milk at $7 d$. per gallon. The British Farmer and his Competitors, p. 126.

4 Second Report of Royal Commission on Agricultural Depression, p. 46.

5 See however the evidence of Sir R. Giffen and Mr. Turmbull before the Royal Commission on Agricultural Depression. The materials for estimating agricultural incomes are there indicatea.

No. 22.-VOL. VI. 
great degree speculative, but the absence of anything of the kind lowers still more the value of the existing statistical data. ${ }^{1}$

A survey of the statistical material as yet provided for estimating Ireland's position in relation to Great Britain leads at once to the request in old legal phraseology for 'further and better particulars.' Indeed, it may be suggested that the units assumed for comparison are too large and too heterogeneous in their composition to allow of the inquiry being scientifically successful. There is no need to dwell on the great diversities of economic conditions in Great Britain, but it is too readily assumed that the economic structure of Ireland is quite simple. Cliffe Leslie long ago pointed out that there was a decided distinction between eastern and western Ireland; the latter being poor and unprogressive, the former showing marks of improvement. ${ }^{2}$ Equally marked is the division between the north-eastern manufacturing district and the remaining region devoted to agriculture. But within these larger areas there are many differences. Thus, Dublin with its professional and artisan population does not stand in the same position as the mountainous districts of Wicklow. Belfast, again, is, economically speaking, of the same class as an English town of the same population. The 'congested districts' are now recognised as being different from the rest of Ireland and requiring special treatment:; ${ }^{3}$ but they are by no means uniform, and some of them shade off into the rest of the country. A fuller statistical account has to be built up from a study of the smaller divisions, and this must necessarily be a slow and laborious task.

1 If guesses are to be allowed, then the gross income-tax assessments might $b_{e}$ taken as the guide in conjecturing the relative proportions of income enjoyed by Great Britain and Ireland respectively. On this assumption whatever be the total income, Ireland's share is assigned; taking e.g. Mr. Bowley's rather high figure of $£ 1,600,000,000$, Irish income would come out at $£ 86,400,000$, an amount quite as defensible as a conjecture as either $£ 63,000,000$ or $£ 76,000,000$.

2 'Draw a line between east and west from Londonderry to Cork, and on the eastern side .... it will be found that the main current is one of progress.' Land Systems, p. 38. I have not been able to find any earlier notice of this important distinction. Dr. Grimshaw has frequently indicated what is substantially the same division, but without any mention of Leslie's prior statement.

3 It may be remarked that to judge from the writings of Inglis and Thackerayto take two well-known instances-all Ireland, a part of Ulster excepted, was a congested district before the famine. 
III.

Remembering then 'the imperfection of 'the statistical record,' and regarding our results as merely provisional, to be taken subject to the corrections that better knowledge would supply, we have to see what general principles are applicable for determining the financial position of Ireland, and what in such a case should be her proper contribution.

At the outset we must decide whether Ireland is to be treated as an integral part of the United Kingdom or as a separate territorial unit. Should the latter view be adopted, it seems certain that the true principle on which taxation should be regulated is that of advantage received. In other words, an estimate must be made of the cost of maintaining the country in independence with the organisation usual for a State of similar size, placed in a like situation. An examination of the budgets of the smaller European nations tends to show that their taxation on the whole exceeds that of Ireland. Thus Belgium, the Netherlands, and Bavaria have much larger revenues. The most instructive instance is, however, Portugal, which has almost exactly the same area and population as Ireland with very similar conditions in other respects. The Portuguese revenue for 1893-4 was estimated at about $£ 9,700,000$, a sum which, with the addition of the local taxation, would much exceed the Irish contribution, however calculated. ${ }^{1}$ Even the increase of expenditure so much complained of has its parallel in other small countries. ${ }^{2}$ An independent Ireland would not, we may feel sure, have lighter taxation than that under the present régime.

Returning to the more solid domain of fact, and regarding the two islands as forming part of a common system, we have next to inquire whether there is any method by which we can assign proportions of the total outlay to the separate parts. Can we distinguish between 'Imperial,' and 'Irish,' 'English,' or ' Scotch '

1 Statesman's Year Book for 1874, p. 834. Portugal is placed in regard to Spain somewhat as Ireland, if separate, would be in respect to Great Britain. Mr. M. O'Brien, in his evidence already referred to, takes Sweden as a parallel, but he underestimates the local taxation of that country, and forgets that an independent Ireland would have a powerful neighbour. As Mill remarks, 'Ireland, besides having to defend herself against all other enemies, internal and external, would feel obliged to keep herself always armed and in readiness to fight England.' England and Ireland, $\mathrm{p}, 28$.

2 Bavarian expenditure in $1819-20$ was $£ 1,600,000$, in 1889 it was $£ 13,000,000$. Between 1835 and 1890 the expenditure of Belgium increased almost five-fold. See my Public Finance (2nd ed.), p. 135. 
services, and if such a distinction is possible, is it legitimate? Public expenditure is obviously devoted to ends that concern the community, and may therefore be plausibly regarded as incurred for the equal advantage of all. What the central government spends is not, on this view, to be debited to any particular portion of the country. All imperial expenditure is, in a word, 'imperial,' while all local expenditure is 'local.' The boundary line is definitely fixed by the division of duties between the central and local authorities. ${ }^{1}$ Unfortunately this dividing line is not always the same: what is a local service in one country is a central one in another. Within the same country, too, the division varies from time to time. Consequently the criterion is deficient in precision. But the error involved is a deeper one. This method of division confuses two essentially different things, viz., the constitutional or administrative point of view with the economic orfinancial one. Whether expenditure is administered by local or central agency is a question of constitutional adjustment; whether a particular form of outlay is for the interest of the whole country or for that of a part can only be decided by an examination of facts. The two principles of division are distinct, for a service may be locally administered, though it is for the general interest, as, e.g., the Poor Law system; or it may be maintained from imperial funds and yet specially benefit a particular district, as in the case of a grant towards a local railway. To regard the 'constitutional' as if it were the 'financial' division is to commit an elementary error. ${ }^{2}$ It is easy, however, to go astray in the opposite direction. Because a particular expenditure takes place in England or in Ireland, it by no means follows that such expenditure is solely for the advantage of the country in which it is incurred. To take a prominent instance, the military outlay in Ireland is not to be debited in full to that country. Barrack accommodation and the lower cost of maintenance are elements in deciding the distribution of troops, and so far as they operate, Ireland is not liable for the higher proportion of soldiers stationed there; but where special disorder makes a larger force needful, special accountability is justified. Thus, if the question is to be treated scientifically, it is absolutely necessary to analyse the whole mass of expenditure, imperial

1 Such seems to be the opinion of Sir R. Giffen, expressed in the most emphatic manner, though he allows the possible existence of theoretical exceptions. See his evidence, Questions 7,796 et sq., 11,019 et sq.

${ }^{2}$ On the principles of division between central and local finance, see my Public Finance, Book I. ch. 7, and Book III. ch. 6. 
and local, in order to assign its due share to each kingdom. More especially does this hold with regard to what is described as 'reproductive' or ' economic' outlay. Here the assets obtained have to be placed against the cost incurred, and when, owing to the diffusion of benefit, no precise revenue can be shown, there is still a gain obtained which offsets and cancels so much tax levy.

A more difficult case is that of unnecessary and wasteful expense. If, as is alleged, Irish services are unduly costly, the remedy lies in retrenchment and reform, and this, it must be said, is in several directions not only possible but highly expedient. ${ }^{1}$ Still we have to remember that some of the instances of higher payment are due to physical or social conditions rather than to mere extravagance. The Post Office in Ireland is worked at a loss $;^{2}$ and the cost of police is for obvious reasons much greater than in England. Inequalities of this kind are not without parallels. Local rates, as Mr. Cannan has shown, ${ }^{3}$ are very unequal owing to various causes, amongst which physical conditions are one, and so far as such influences are economic in their action it is not well to counteract them. On the whole, it seems unquestionable that the expenditure side of the Irish relation to the United Kingdom should be considered as well as the revenue one, and that the attempt to distinguish between expenditure that is ' Irish ' and what is purely 'Imperial' is in aecordance with, indeed is prescribed by, financial principle. ${ }^{4}$

Passing from the question of expenditure to that of receipts, we meet with several familiar problems in a somewhat novel connexion. The principles that should govern the contributions of classes towards the public services have been elaborately discussed, but the distribution of burdens amongst the ' countries' making up a larger State has not received much attention. For this apparent neglect at least three reasons may be assigned. In the first place, when dealing with distinct countries, the idea of

1 A thorough examination of the judicial and administrative expenditure in Ireland would establish the need for reform which would at the same time conduce to greater efficiency.

2 For 1892-3 the revenue is given as $£ 740,000$, the expenditure as $£ 790,000$, deficit $£ 50,000$. See Returns as to 'Government of Ireland Bill (Financial Effects),' No. 91, 1893.

3 See his excellent paper 'Inequality of Local Rates,' Economic Journal, Vol. V., pp. 22-34.

4 It does not, however, follow that any particular attempt at classification is correct. The effort in this direction made by Sir E. Hamilton, though it would be unjust to characterise it as 'purely arbitrary,' seems to require much revision and readjustment. 
advantage obtained is more prominent than that of relative resources. The work that the Government has to do should, it is thought, be paid for at its 'fair' value, which is independent of the wealth or poverty of the purchaser. ${ }^{1}$ Again, in most cases of the kind the federal relation-or, at all events, separate tax systems-is the form adopted, so that none but admittedly common expenses are defrayed from the central treasury, and the particular quotas are arranged by adjustment and compromise rather than by scientific calculation. ${ }^{2}$ But the third reason has been the most influential, viz. : the belief that in the unitary state local divisions have ceased to be of importance and that the State deals directly with individuals. Therefore it follows that taxation which is equal as between the different persons forming the society must of necessity be equal as between the different territorial divisions. ${ }^{3}$ The question of the due adjustment of the burden of taxation in the latter case has accordingly been neglected, or regarded as practically non-existent.

That there is an important element of truth in this conception of the unity of the State transcending and obliterating all minor divisions may be freely admitted. It has the further advantage of placing emphasis on the fact that in the ultimate analysis all taxation falls on some person or persons. The under (or over) taxation of Ireland can only mean that some or all of its inhabitants pay less (or more) than their due share. 'Ireland' is simply a general term for Irish tax-payers, ${ }^{4}$ and it is the pressure on those tax-payers that has to be considered. Vague talk about 'robbery of ' or 'injustice to' a country is not a substitute for examination of the real incidence of taxation. There is nevertheless nothing incorrect in taking Ireland and Great Britain in the only intelligible meaning of those terms as ' units' for the purpose of financial comparison. Such an inquiry is quite as legitimate as a discussion of the relative burdens of 'landowners' and

1 It might be plausibly argued that a very poor country receives special advantage by its union with a rich one, and further that governmental services are of greater utility to it.

2 The distribution of the forms of taxation between the 'Empire,' the 'States,' and the 'Communes' has been discussed by German writers on Finance. See Schäffle, Steuerpolitik, p. 559 et sq.; Cohn, Finanzwissenschaft, Book III. ch. 1.; Wagner, Finanzwissenschaft, p. 81 et sq.

3 This was the view formerly taken by Mr. Gladstone, and even more emphatically by Mr. Lowe.

${ }^{4} C f$. the remarks of Sir R. Giffen as to taxation falling on 'property.' Second Report of Commission on Agricultural Depression, pp. 46, 47. Cf. also, 'It is never things but always persons that pay rates and taxes.' Cannan, History of Local Rates, p. 22. 
'capitalists.' The complications surrounding, and the weakness of the statistical data needful in, investigations of the kind are reasons for caution in drawing conclusions, not an absolute bar to inquiry. The same tests that apply to individuals or to special classes are equally in place for the large classes formed by the populations of countries.

Amid the protracted controversies that gather round financial questions one propesition stands out as receiving almost unanimous assent. Writers of the most opposed views in other respects agree in accepting 'ability' or 'capacity' as the measure of contribution, and there is nearly as general recognition of the fact that this ability or capacity is in some way related to 'income.' Material divergence of opinion only begins in respect to the nature of this relation. One school maintains that income by itself is a sufficient measure of capacity, taxation should therefore be in direct proportion to amount of income in the case either of individuals or of classes. Another view, supported by high authority, regards, not income as a whole, but surplus income as affording the criterion of taxable ability. Necessary expenses should, it is thought, be exempt, and the tax rates should be fixed in proportion to the residue. Though expressed in varying forms, this is the essential point of the doctrine, and it is one that deserves attention. Contribution from a bare subsistence minimum is obviously impossible, and cannot therefore be enforced. With regard, however, to incomes above that amount, the claim for exemption of 'a portion equal to the minimum seems unfounded, or at the utmost is only applicable where the surplus is very small. In any case the attempt to create an artificial minimum by assigning a supposed standard of living has little scientific justification. A family able to maintain a decent existence may justly be asked to pay for one of the conditions necessary for the continuance of that state. ${ }^{1}$ But the decisive objection to such theories is the difficulty of their practical application. To estimate income is a task, perhaps, too difficult for the statistician; but to discover the amount of 'free' income is quite hopeless, and the employment of conjectural amounts as guides in so definite a matter as taxation is a dangerous course which might lead to the most paradoxical

1 What Sir R. Giffen describes as 'Mill's principle of allowing a minimum for subsistence per head before taxation should begin-say $\$ 12$ per head' (Financial. Relations Commission, vol.ii. p. 166) is, as he applies it, inconsistent with Mill's view that the exemption should be conditional on the minimum income being spent wholly on necessaries. It may be noted further that Mill's minimum point was decidedly lower. 
results. ${ }^{1}$ A slight alteration of figures would supply the premises for an altogether different conclusion. ${ }^{2}$

The difficulties inherent in any attempt to refine on or manipulate the total income in order to get a measure of ability seem to indicate the convenience of keeping to the plain rule of taxation according to income, so far as that is ascertainable. Applying this test to the special case before us, it is plain that the direct taxes levied in the United Kingdom give no cause of complaint to Irishmen. Both the income tax and the death duties press lightly on the Irish population. But when we pass to the other great head of revenue-the taxes on commodities-a different condition of things is found. The excise and customs show a much heavier Irish contribution. Instead of yielding less than one-twentieth of the total receipts, as in the case of the direct taxes, the receipt is about one-ninth, an amount clearly out of proportion to the relative income. ${ }^{3}$ Nor is there any difficulty in discovering how this inequality is produced. Tea, tobacco, and spirits, all objects of comparatively large consumption in Ireland, are specially selected for taxation and therefore afford a considerable yield. The immediate result is to place an undue part of the burden of taxation on the poorer classes. There does not seem to be the slightest ground for believing that the middle or upper class Irishman is more taxed than he would be if he happened to reside in England or Scotland. Descending lower in the economic scale, the artisan or comfortable farmer does not appear to have any special grievance. The pressure falls on the poorer sections of the agricultural class and the unskilled labourers. Thus, the question-as will happen with most questions arising under a common system of taxation-becomes

1 One pertinent instance may be given here. In 1886 Sir R. Giffen estimated the taxable surpluses of Great Britain and Ireland respectively at 800 millions and 15 millions; in 1895 he estimated them at 900 millions and 22 millions. From which it at once follows that Ireland's taxable capacity had risen from being less than 1:53 to more than 1:41; or to put the matter in another way, while Great Britain's surplus had increased $12 \frac{1}{2}$ per cent. Ireland's had increased $46 \frac{2}{3}$ per cent. Thus it would seem that Ireland is gaining on Great Britain, and that if inequality in taxation exists it is being diminished.

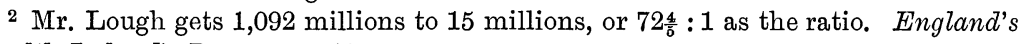
Wealth Ireland's Poverty, p. 107.

3 Though the statistics as to the comparative incomes of Great Britain and Ireland are too speculative for direct use, they suffice to show that the amount per head is much lower in Ireland than in Great Britain. It is perhaps going too far to say that the Irish average is only one-half of the British one, but of the great inferiority there can be no doubt. Granting that the proportion of income tax and death duties does not give a true idea of the total Irish income, it is yet unquestionable that the taxes on commodities go too far on the other side. 
one of classes rather than of countries. By this mode of procedure the problem is greatly simplified. The elaborate estimates of income are reduced to their proper place as suggestive indications to be used within wide limits rather than as accurate guides. T'he equally difficult question of extra expenditure is transferred to the domain of administrative reform or redistribution between central and local finance. Granting that 'Ireland' receives back in additional expenditure what the taxes on commodities levy from some Irish consumers, that is no recompense to the particular sufferers unless they can be shown to have specially gained. Thus re-adjustment of such taxation as exceeds the due amount seems to be the obvious suggestion. If some charges are too high the plain, indeed the only sound, remedy is to be found in a lower scale of duties. The chief commodities taxed are not, however, to be all placed in the same category. Tea, as an article of general consumption, and as harmless if not beneficial in its use, has the best claim to relief. Though there are, no doubt, some grounds for keeping the taxation of commodities on a wider basis, yet the case for a free breakfast table is a strong one, and by the adoption of that policy a material step towards relief of the poorer classes would be made. Tobacco is in a different situation; its use is often excessive, and scarcely ever necessary. The duty on it has the great advantage of counterbalancing the direct taxes on the higher incomes, and, so far as the coarser qualities are concerned, is in fact a poll tax freed from objectionable incidents. Still this duty would admit, if just distribution requires it, of abatement, and some further favour could be shown to the poorer kinds chiefly- used by the labourer. Last in the list come the spirit duties, which are admittedly levied at a very high rate, and therefore fall with severity on Ireland and Scotland, where the average consumption is high. But it need hardly be said that these duties are not purely fiscal. They are assumed to act as a deterrent on consumption, and are regarded as having a moralising aim. It is significant that nearly all civilised countries have adopted the same policy and placed peculiarly heavy charges on alcohol as distinguished from the lighter and more nutritive beverages. ${ }^{1}$ A class of duties resting on this principle is not to be confounded with others of a different kind. Arthur Young's emphatic statement already quoted, ${ }^{2}$ shows that, in his opinion, heavy taxation of whisky was likely to prove a public advantage.

1 This has been the policy of France, Russia, and the United States.

${ }^{2}$ Supra, p. 186. 
Under these circumstances there appears to be no reason for remitting duties which tend to restrain injurious consumption, nor can it be said that an unjust burden is placed on the country in which the consumers of such a commodity are most numerous. ${ }^{1}$

The foregoing examination of the Irish contributions to the imperial exchequer suggests some points of importance in respect to the British financial system as a whole. First, its treatment of the more poorly paid labourers as compared with that of the more skilled artisans. At present the labourer with 12s. or 15s. per week may, and probably does, pay as much in taxation as the tradesman with $£ 110 s$. or $£ 115 s$. per week. Indirect taxation, combined with direct, may bring about a rough proportion between the working, the middle, and the upper classes; but when limited to a few commodities it appears to press unfairly on the weakest section of the first-named class. The great body of labourers with low wages in Ireland brings this point out strongly in her case, but the inequality exists in both countries between the lower and higher paid workers. ${ }^{2}$ A second point is the dependence of the revenue system on the productiveness of the drink duties: About $£ 32,000,000$ was the last year's receipt from this source. Were any check put to the consumption it is hard to conjecture what substitute could be procured. It is probable that much heavier direct taxation would become necessary, with a very serious shifting in the incidence of the burden. Whether it will be permanently possible to maintain the revenue systems of civilised countries by the taxation of a special kind of harmful luxuries is one of the gravest questions for the financiers of the future. Thirdly, the due balance between local and imperial finance is hard to arrange. The many gratuities advanced to local bodies should be replaced by a more scientific system. Thus the difficulties as to excess expenditure in some districts can be solved only by a comprehensive adjustment of local and central

1 Two opposed views respecting taxes on commodities are open to criticism. One which maintains that 'in a free country' a person may consume what he pleases, though it breathes a liberal spirit, is directly opposed to the policy of every civilised country and to the highest financial authority. Even an advocate of laissez-faire who believed in the 'benefits' theory of taxation might approve of making the consumers of intoxicating drinks pay for the crime and cost to the State resulting from drunkenness. On the other hand, I should dissent from the view-supported by the high authority of Mr. Sidgwick-that taxation of commodities is lighter in its pressure than direct taxation. On the contrary, the latter seems to me to be quite as light and fairer in its incidence ; the technical difficulties are the obstacle to its employment. Cf. J. S. Mill, Principles, Book V., ch. vi. § 1.

2 The wages of artisans in Ireland have always been comparatively high. See Young, Tour in Ireland, vol. ii. p. 53. Crumpe, Essay, pp. 187, 188. 
revenue. Bounties given through favour or pressure are always objectionable. The place of Ireland is but one example of a wide class of cases that stands in urgent need of effective treatment.

To conclude. It would appear that the historical relation of Ireland to Great Britain has been that of a protected dependency ending in complete fiscal union. There seems to be no mode of calculating the loss or gain that occurred during the various phases of this development. The statistical data on which much of the discussion as to Irish over-taxation has been based are too speculative for practical employment. Quite apart from comparisons of such small scientific value there seems to be good reason for a relaxation of burdens on the poorer classes in Ireland as in other parts of the United Kingdom; but such adjustment would be best attained by removal of the existing tea duty and a modification of the tax on tobacco. It would accordingly seem to be a mistake to present the case as one of Ireland versus Great Britain. It is rather to be urged as a claim of the classes with low wages versus the better paid workers and the lower middle class.

C. F. Bastable 